\title{
Microbial quality, physicochemical characteristics and fatty acid composition of a traditional butter produced from cows' milk in East Algeria
}

\author{
By Tayeb Idoui, ${ }^{*}$ Nabila Benhamada and Essaid Leghouchi \\ Laboratory of Pharmacology and Phytochemistry, University of Jijel, Jijel (18000) Algeria \\ ( ${ }^{\star}$ Corresponding author: tay_idoui@yahoo.fr)
}

\section{RESUMEN}

Calidad microbiológica, características fisicoquímicas y composición en ácidos grasos de una mantequilla tradicional producida con leche de vaca del Este de Argelia.

Esta es la primera vez que se describen las propiedades microbiológicas y fisicoquímicas y la composición en ácidos grasos de una mantequilla tradicional producida con leche de vaca del Este de Argelia. Cinco muestras de mantequilla fueron preparadas en el laboratorio siguiendo el método tradicional usado por la población del área de Jiels (Este de Argelia). Nuestros resultados muestran la presencia de ácido láctico, bacterias psicrotróficas y levaduras, mientras que stafilococos y bacterias lipolíticas no fueron detectadas. Importantes diferencias fueron encontradas en los valores químicos de las diferentes muestras de mantequilla. Los valores de $\mathrm{pH}$ variaron entre 4.64 y 5.53. La humedad e impurezas excedió el $17.5 \%$ y $9.19 \%$, respectivamente. Los valores de índice de acidez, índice de peróxidos, índice de saponificación e índice de yodo variaron entre: $23.56-31.35 \mathrm{mg} \mathrm{KOH} / \mathrm{g}, 1.6-4 \mathrm{meq} / \mathrm{kg}, 140.25-$ $228.60 \mathrm{mg} \mathrm{KOH} / \mathrm{g}$ and $35.35-53.69 \mathrm{mgl} / 100 \mathrm{~g}$, respectivamente. Finalmente la composición de ácidos grasos mostro que el ácido palmítico y el ácido oleico fueron los principales ácidos grasos saturados e insaturados, respectivamente.

PALABRAS CLAVE: Ácido graso - Fisicoquímica Mantequilla tradicional - Microflora.

\section{SUMMARY}

Microbial quality, physicochemical characteristics and fatty acid composition of a traditional butter produced from cows' milk in East Algeria.

This is the first report describing microbiological, physicochemical properties and fatty acid composition of a traditional butter produced from cows' milk in East of Algeria. Five butter samples were prepared in the laboratory according to the traditional method used by people in the Jijel areas (Eastern Algeria). Our results show the presence of lactic acid and psychrotrophic bacteria as well as yeasts, while staphylococci or lipolytic bacteria were not detected. Important differences were found in chemical values among butter samples. The $\mathrm{pH}$ values ranged from $\mathrm{pH} 4.64$ and $\mathrm{pH} 5.53$. Moisture and impurities exceeded $17.5 \%$ and $9.19 \%$ respectively. The values for acid index, peroxide index, saponification index and iodine index ranged from: $23.56-31.35 \mathrm{mg} \mathrm{KOH} / \mathrm{g}, 1.6-4 \mathrm{meq} / \mathrm{kg}, 140.25-$ $228.60 \mathrm{mg} \mathrm{KOH} / \mathrm{g}$ and $35.35-53.69 \mathrm{mgl} / 100 \mathrm{~g}$ respectively. Finally, the fatty acid composition showed that palmitic acid and oleic acid were the major saturated and unsaturated fatty acids.

KEY-WORDS: Fatty acid - Microflora - Physicochemical - Traditional Butter.

\section{INTRODUCTION}

A wide variety of products are manufactured by processing raw milk into dairy products. Among them, butter is one of the primarily fat sources and an important source of dietary energy. It has been produced since ancient times and was an internationally traded commodity as early as the $14^{\text {th }}$ century (Vernam and Sutherland, 1994; Rady and Badr, 2003).

Butter is widely used as a seasoning in cooking, suggesting that it plays an important role in the formation of flavors during heating (Peterson and Reineccius, 2003; Ito et al., 2005). Besides fats, butter contains small percentages of proteins, milk sugar and water which make it a suitable substrate for microorganisms (Catsberg and Kempen-van Dommelen, 1990). Although butter spoilage is most often due to the development of chemical rancidity, microbiological problems do also occur in the form of cheesy, putrid or fruity odors and the rancid flavor produced by hydrolysis (Rady and Badr, 2003). Many psychrotrophic strains of bacteria, yeasts and moulds have been implicated in spoilage and lipolysis of butter at temperatures below $5^{\circ} \mathrm{C}$ and some even below $0^{\circ} \mathrm{C}$. Moreover, some pathogenic bacteria such as Staphylococcus aureus and Listeria monocytogenes remained recoverable in butter stored in low temperatures (Collins et al., 1989).

Traditional Algerian dairy products, especially the fermented types, have been the pride of culinary tradition for centuries. It is evident that these products have played a major role in the diet of communities in the rural region. Among those, Iben, raib, dhan or zebda or sman and jben are the most common and are being increasingly marketed throughout the country in informal ways.

The traditional stages of the manufacturing of Dhan are the following: Raw milk is left to sour spontaneously at ambient temperature until coagulation occurs which may take up to 24-72 h depending on the temperature during the summer and winter seasons. On gelation, the product is called rayeb, and may be consumed as such; however, by churning the fermentate, the product is separated into lben and raw butter called Dhan 
or zebda literally meaning 'butter of the county' (in other Middle Eastern countries the same product is known as zibdeh baladieh, samna and in some instances, the mutton fat dripping is also samen or samneh). In the rest of the world the butter-related product is known as butter oil, ghee or anhydrous milk fat (Benkerrouma and Tamime, 2003).

To our knowledge, no information exists on the quality of traditional butter produced in eastern Algeria and especially in the Jijel area. The aim of this study was to describe microbiological, physicochemical properties and fatty acid composition of a traditional butter called "Dhan" produced from cows' milk in the Jijel area (East of Algeria).

\section{MATERIALS AND METHODS}

\subsection{Samples}

Traditional cows' butter was manufactured in our laboratory as described in the introduction. Five fresh cows' milk samples were collected from different locations of Jijel (Eastern Algeria). They were left in the laboratory at ambient temperature for two days. After spontaneous coagulation, Raib was churned, and traditional butter called Dhan was recovered.

\subsection{Microbiological analysis}

For each sample, the liquid phase was separated as described by Idoui and Karam (2008) and Idoui et al. (2009). Samples were heated at $45^{\circ} \mathrm{C}$ and then centrifuged at $3000 \mathrm{rpm}$ for $15 \mathrm{~min}$. The intermediate liquid phase was separated and then decimal dilutions were carried out.

The media and the conditions for microbial counting were as follows (Leveau and Bourgeois , 1980; Collins et al., 1989; Roberts et al., 1995): Plate count agar incubated at $30^{\circ} \mathrm{C}$ for $48-72 \mathrm{~h}$ for total bacteria; violet red bile agar, incubated at $37^{\circ} \mathrm{C}$ for $24 \mathrm{~h}$ for total coliforms; Baird-Parker agar base, incubated at $37^{\circ} \mathrm{C}$ for $48 \mathrm{~h}$ for staphylococci; MRS agar, incubated at $32^{\circ} \mathrm{C}$ for $48 \mathrm{~h}$ to $72 \mathrm{~h}$ in anaerobiosis for lactic acid bacteria; oxytetracyclin glucose agar, incubated at $25^{\circ} \mathrm{C}$ for 3-7 days for yeasts, plate count agar with $5 \%$ of sterilized cream incubated at $25^{\circ} \mathrm{C}$ for $72 \mathrm{~h}$ to 5 days for total lipolytic bacteria; plate count agar incubated at $6^{\circ} \mathrm{C}$ for 7 to 10days for psychrotrophic bacteria; plate count agar with $5 \%$ of sterilized skim milk incubated at $37^{\circ} \mathrm{C}$ for $48 \mathrm{~h}$ to 72 days for total caseolytic bacteria.

\subsection{Physicochemical analysis}

Impurities and moisture were determined according to the method described by Lecoq (1965).

Acid index, peroxide index and saponification index were performed according to the methods described by Lecoq (1965).

For the butter acidity, a known weight was dissolved in a mixture of diethyl ether / ethanol. The mixture was titrated with potassium hydroxide in methanol $(0.05 \mathrm{M})$ in the presence of phenolphthalein as indicator. For peroxide index, a known weight was dissolved in a mixture of acetic acid/ chloroform $(3: 2 \mathrm{v} / \mathrm{v})$, and a saturated solution of $\mathrm{KI}$ was then added. The liberation iodine was titrated with a sodium thiosulphate solution in the presence of starch as indicator. For saponification index, a known weight of butter was dissolved in alcoholic potassium hydroxide then evaporated for $30 \mathrm{mn}$. The sample was titrated with chlorydric acid $(0.5 \mathrm{~N})$ in the presence of phenolphthalein as indicator.

\subsection{Analysis of fatty acids}

The butter samples were esterified in a methanol solution of $2 \mathrm{~N} \mathrm{KOH}$ for 30 minutes at $50^{\circ} \mathrm{C}$. The gas chromatographic analysis of fatty acid methyl esters was performed on a Perkin Elmer gas chromatograph, equipped with a flame ionization detector (Shimadzu QP2010): The column was a fused silica capillary SE30 length 25meters, diameter $0.25 \mu \mathrm{m}$. Helium was the carrier gas. The column temperature program was: initially isotherm at $140^{\circ} \mathrm{C}$ for $10 \mathrm{~min}$, an initial programmed rate of $1^{\circ} \mathrm{C} / \mathrm{min}$ up to $160^{\circ} \mathrm{C}$, then a second rate of $2^{\circ} \mathrm{C} / \mathrm{min}$ up to $220^{\circ} \mathrm{C}$ and a final isotherm for $15 \mathrm{~min}$. Samples were injected into the split mode. The apparatus itself carried out recording and integration.

The gas-chromatographic peaks were identified as corresponding fatty acid methyl esters by checking the elution order on the column and comparing the retention times with those of pure standards.

\section{RESULTS AND DISCUSSION}

\subsection{Microbiological characteristics}

Table 1 shows the counts of total bacteria, total coliforms, staphylococci, lactic acid bacteria, yeasts, total lipolytic bacteria, total caseolytic bacteria and psychrotrophic bacteria recorded in traditional butter samples.

Butter samples have a relatively high total bacterial count reaching $60 \times 10^{5} \mathrm{cfu} / \mathrm{g}$. These results are in agreement with those reported by Rady and Badr (2003). Kacem and Karam (2006) reported the high count of aerobic bacteria in traditional butter made from camel milk (mean log counts 2.76 to 3.88). The high count of total bacteria may be attributed to the absence of pasteurization and salt. Adam and Moss (1995) attributed the increase of total bacteria to the effect of both separation and churning processes on the breaking up of bacterial clumps which increases their number.

Lipolytic bacteria were not detected in any of the analyzed samples. This result is not in agreement with those reported by Rady and Badr (2003). These authors reported the presence of lipolytic bacteria in all butter samples. The same results were obtained with the count of staphylococci. Also, total coliforms 
Table 1

Counts of microbial populations in traditional butter samples

\begin{tabular}{lccccc}
\hline \multicolumn{1}{c}{ Sample } & $\mathbf{0 1}$ & $\mathbf{0 2}$ & $\mathbf{0 3}$ & $\mathbf{0 4}$ & $\mathbf{0 5}$ \\
\hline Total bacteria $\left(10^{4} \mathrm{cfu} / \mathrm{g}\right)$ & 15 & 600 & 20 & 32 & 20 \\
Total coliforms $\left(10^{4} \mathrm{cfu} / \mathrm{g}\right)$ & $\mathrm{ND}$ & 0.2 & 00 & 00 & 00 \\
Staphylococci $(10 \mathrm{cfu} / \mathrm{g})$ & 00 & 00 & 00 & 00 & 00 \\
Lactic acid bacteria $\left(10^{4} \mathrm{cfu} / \mathrm{g}\right)$ & 1.04 & 1.36 & 1.05 & 5.55 & 0.6 \\
Yeasts $\left(10^{4} \mathrm{cfu} / \mathrm{g}\right)$ & 0.275 & $\mathrm{ND}$ & 0.01 & 0.505 & 0.03 \\
Total lipolytic bacteria $\left(10^{3} \mathrm{cfu} / \mathrm{g}\right)$ & 00 & $\mathrm{ND}$ & 00 & 00 & 00 \\
Total caseolytic bacteria $\left(10^{4} \mathrm{cfu} / \mathrm{g}\right)$ & 0.4 & 00 & 0.15 & 1.45 & 0.4 \\
Total Psychrotrophic bacteria(10 $\mathrm{cfu} / \mathrm{g})$ & 0.38 & 0.128 & 1.27 & 3.6 & 4.6 \\
\hline ND: Not determined & & & & &
\end{tabular}

were present in one out of five samples $\left(02 \times 10^{3}\right.$ $\mathrm{cfu} / \mathrm{g}$ ). It is not in total agreement with the results reported by some authors (Hassan, 1984; Rady and Badr, 2003; Kacem and Karam, 2006).

The Data given in table 1 indicate that butter samples had a high lactic acid bacteria count ranging from $0.6 \times 10^{4} \mathrm{cfu} / \mathrm{g}$ (sample 05) to $5.55 \times 10^{4}$ cfu /g (sample04). Similar results were reported in earlier studies on butters (Kacem and Karam, 2006; Idoui and Karam, 2008; Idoui et al., 2009). Also, results reveal that samples had a high yeast count, it exceeded $0.1 \times 10^{3} \mathrm{cfu} / \mathrm{g}$. These results are not surprising because yeasts were routinely isolated from these products. In a previous study, yeasts and moulds have been detected with high counts in butter (Rady and Badr, 2003; Kacem and Karam, 2006). In a study conducted by El Marrakchi et al. (1988), a microbial analysis of commercial smen showed that yeast counts, when present, exceeded $10^{6} \mathrm{cfu} / \mathrm{g}$. Their high counts and well known high lipolytic activity suggest that yeasts may play an active role in smen ripening.

From these results, it appears that caseolytic bacteria represent an important part of the bacterial microflora of traditional butter, as counts in different samples range from $1.5 \times 10^{3} \mathrm{cfu} / \mathrm{g}$ to $14.5 \times 10^{3}$ $\mathrm{cfu} / \mathrm{g}$. The presence of this microflora has not been reported in any previous study. Finally, our results reveal that the control butter samples had a count ranging from $1.28 \times 10^{3} \mathrm{cfu}$ to $46 \times 10^{3} \mathrm{cfu} / \mathrm{g}$ for psychrotrophs bacteria. These results agreed with those reported by Kacem and Karam (2006).

\subsection{Physicochemical characteristics}

The physicochemical characteristics of traditional butter samples are shown in table 2. As shown, important differences were found in chemical values among butter samples. $\mathrm{pH}$ values of samples ranged from $\mathrm{pH} 4.64$ and $\mathrm{pH} 5.53$. Similar results are found by Sagdic et al. (2002). In a study conducted by Kacem and Karam (2006), the pH values of smen made from camel milk varied in all samples between pH3.11 and $\mathrm{pH}$ 4.97. In the same table, moisture and impurity values of butter samples ranged from $17.5 \%$ and $26.5 \%$, and $9.19 \%$ and $23.5 \%$ respectively. These values are higher than the limits established for industrial butter but they were lower than the values found by Sagdic et al. (2002) and Kacem and Karam (2006). In a similar study conducted by Hamama (1997) on the traditional raw butter produced in Morocco, the moisture value was $23 \%$.

As shown in table 2, acid index, peroxide index, saponification index and iodine index of butter samples varied according to the samples of butter and locations. Acid index was in the range of 23.56 $\mathrm{mg} \mathrm{KOH} / \mathrm{g}$ in sample 04 and $31.35 \mathrm{mg} \mathrm{KOH} / \mathrm{g}$ in the butter of sample 02. These results are not in total agreement with those reported by Rady and Badr (2003). Benkerroum and Tamime (2004) reported that the acid index values in Moroccan raw butter and smen were respectively 2.4 and $52 \mathrm{mg} \mathrm{KOH} / \mathrm{g}$. On the other hand, the peroxide index values ranged between 1.6 meq $\mathrm{O}_{2} / \mathrm{kg}$ and 4 meq $\mathrm{O}_{2} / \mathrm{kg}$ of butter. In Moroccan raw butter and smen, Benkerroum and Tamime (2004) reported that peroxide index values were 0.5 and 3.7 meq $\mathrm{O}_{2} / \mathrm{kg}$ of fat respectively. The same authors reported that some proteolysis of the residual milk proteins in the aqueous phase may occur, lipolysis is the primary mechanism which determines the typical flavor of the product and such activity could originate from the microbial cells and/or free lipases. Chemical oxidation also contributes to a lesser degree to the flavor of smen; this is evident as the peroxide value increases to $3.7 \mathrm{meq} / \mathrm{kg}$ of fat compared to $0.5 \mathrm{meq} / \mathrm{kg}$ in fresh raw butter. The results obtained also indicated that the saponification index exceed $140.25 \mathrm{mg} \mathrm{KOH} / \mathrm{g}$ of butter and in all samples the iodine index (35.35 $\mathrm{mg} \mathrm{l} / 100 \mathrm{~g}-53.69 \mathrm{mg} \mathrm{l} / 100 \mathrm{~g}$ of butter) was higher than reported by Rady and Badr (2003).

\subsection{Fatty acid composition}

The fatty acid composition of traditional butter is not documented. Nineteen (19) fatty acids are identified (Table 3). As shown, important differences were found in fatty acid compositions among butter samples. Traditional cows' butter contained a high percentage of saturated fatty acids (SFA) and palmitic acid was the major SFA $(24.33 \%-36.95 \%)$ followed by myristic acid (18.49\%- $27.35 \%$ ) and 
Table 2

Chemical and physical properties of traditional butter

\begin{tabular}{lccccc}
\hline \multicolumn{1}{c}{ Sample } & $\mathbf{0 1}$ & $\mathbf{0 2}$ & $\mathbf{0 3}$ & $\mathbf{0 4}$ & $\mathbf{0 5}$ \\
\hline $\mathrm{pH}$ & 4.64 & 5.53 & $\mathrm{ND}$ & $\mathrm{ND}$ & $\mathrm{ND}$ \\
Acid Index (mg KOH/g) & 24.75 & 31.35 & 27.12 & 23.56 & 26.36 \\
Peroxide Index (meq / kg) & 1.6 & 2.4 & 4.0 & 4.0 & 3.0 \\
Saponification Index (mg KOH/g) & 140.25 & 168.3 & 196.35 & 224.74 & 228.60 \\
lodine Index (mg l/100g) & 35.35 & 48.04 & 53.69 & 48.33 & 36.55 \\
Moisture (\%) & 26 & 17.5 & 26.2 & 18 & 20 \\
Impurities (\%) & 16 & 23.5 & 11.14 & $\mathrm{ND}$ & 9.19 \\
\hline
\end{tabular}

ND: Not determined

Table 3

Fatty acid profiles of traditional butter samples (peak area \%)

\begin{tabular}{lccccc}
\hline Sample & 01 & $\mathbf{0 2}$ & $\mathbf{0 3}$ & $\mathbf{0 4}$ & $\mathbf{0 5}$ \\
\hline Fatty acids & $\mathbf{0 1}$ & - & - & - & - \\
\hline Valeric Acid & 7.90 & 6.73 & - & - & - \\
Lauric Acid & - & 18.49 & 27.35 & 23.92 & 24.24 \\
Myristic acid & - & - & - & 2.13 & - \\
12-Tetradecanoic acid & 8.87 & - & 2.55 & 3.03 & 2.12 \\
Pentadecanoic acid & 24.33 & 34.90 & 31.01 & 36.95 & 30.28 \\
Palmitic Acid & - & - & - & - & 0.63 \\
14-Hexadecanoic acid & - & - & 0.48 & 0.51 & 0.61 \\
Heptadecanoic acid & - & - & - & 1.09 & - \\
Heneicosanoic acid & - & - & - & 0.98 & - \\
Triacontanoic acid & 13.45 & 8.19 & 7.68 & 11.08 & 14.05 \\
Stearic Acid & - & - & 19.32 & - & 4.75 \\
Unknown & - & - & 1.45 & - & 1.32 \\
9- Hexadecenoic acid & 11.01 & - & - & - & - \\
2-propenoic acid & - & 20.54 & - & - & - \\
8- Octadecenoic acid & 13.99 & - & 7.41 & 15.08 & 14.75 \\
Oleic acid & - & - & 2.76 & 3.43 & - \\
10-Octadecenoic acid & 4.03 & - & - & - & - \\
Vaccenic acid & - & - & - & 1.60 & - \\
6,9-Octadecadienoic acid & 7.03 & 11.15 & - & - & - \\
Linoleic Acid & & & & & \\
\hline
\end{tabular}

stearic acid (7.68\%-14.05\%). These results are not in total agreement with those reported by Rady and Badr (2003). These authors reported that palmitic acid was the major SFA (22.81\%) followed by stearic acid $(10.21 \%)$. The predominance of palmitic acid was also previously reported with similar trends for other major fatty acids in milk fat (Gunstone, 1996; Dorey et al.,1988) and butter fat (Dorey et al.,1988). In a study conducted by Ito et al. (2005) heated butter contained $27.60 \%$ palmitic acid. On the other hand, linoleic acid was solely present in samples 1 and 2 while oleic acid was the predominant mono unsaturated fatty acid (7.41\%- 15.08\%). This result is in agreement with those reported by Rady and Badr (2003) and Ito et al. (2005). As shown in table 3 , some fatty acids were detected such as valeric acid, 12-tetradecanoic acid, 14-hexadecanoic acid, vaccenic acid and 6, 9-octadecadienoic acid. These results are not reported in studies conducted on the fatty acid profiles of butter.

\section{CONCLUSION}

It is generally considered that environmental conditions such as temperature, origin and composition of milk, processing and sanitary conditions, etc., might have a significant influence on the microbial and physicochemical composition of traditionally made dairy products. From these results we can conclude that important differences were found in microbial quality, physicochemical characteristics and fatty acid 
composition of a traditional butter produced from cows' milk. Thus, the present study is expected to encourage more research such as microbial diversity and physicochemical composition in traditional Algerian butter.

\section{ACKNOWLEDGEMENTS}

This work was supported by a grant of the "Ministère de l'Enseignement Supérieur et de la Recherche Scientifique" of Algeria (Project: F01720080009).

\section{REFERENCES}

Adam MR, Moss MO. 1995. Food microbiology, $1^{\text {st }}$ Ed. R.Sc., Cambridge, CB4 4WF.

Benkerrouma N, Tamime AY. 2003. Technology transfer of some Moroccan traditional dairy products (Iben, jben and smen) to small industrial scale. Food. Microbiology. 21, 399- 413.

Catsberg CME., Kempen-van Dommelen GJM. 1990. Food handbook, $1^{\text {st }}$ English Ed. Ellis Harwood, New York.

Collins CH, Lyne H, Patricia M, Grange JM.1989. Collins and Lyne's microbiological methods, $6^{\text {th }}$ Ed. Butterworths, London.

Dorey F, Brodin D, Le Querler JF, Kuzdzalsavoie S.1988. Analyse des acides gras du beurre par chromatographie en phase gazeuse couplée avec la spectrometrie de masse. Ind. Aliment. Agric. 10, 437442.

El Marrakchi A, Tantaoui-Elaraki A, El Mane A, Tifrit L. 1988. La flore microbienne du smen marocains. I. Flore naturelle et flore d'intérêt hygiénique. Lait. 68, 205-218.

GunstoneFD. 1996. Fatty acid and lipid chemistry, $1^{\text {st }}$ Ed. Chapman and Hall, London.

Hamama A. 1997. Improvements of the manufacture of traditional fermented products in Morocco: case of jben (Moroccan traditional fresh cheese). In: Dirar, H.A. Ed. Emerging Technology Series-Food Processing Technologies for Africa. UNIDO, Vienna.

Hassan MNA. 1984. Safety of food irradiation process underlined by three international organizations. IAEA, Vienna.

Idoui T, Karam NE. 2008. Lactic acid bacteria from Jijel's traditional butter: Isolation, identification and major technological traits. Grasas y Aceites 59, 361-367.

Idoui T, Leghouchi E, Karam N. 2009. Lactic acid bacteria from "Sheep's Dhan", a traditional butter: Isolation, identification and major technological traits. Grasas y Aceites 60, 177-183.

Ito N, Wada S, Yamanaka Y, Takagaki H, Nakamura $\mathrm{H}$. 2005. Identification of novel decenoic acids in heated butter. Biosci.Biotech. Biochem. 69, 2416- 2420.

Kacem M, Karam NE. 2006. Physicochemical and microbiological study of "shmen", a traditional butter made from camel milk in the sahara (Algeria): isolation and identification of lactic acid bacteria and yeasts. Grasas y Aceites 57, 198-204.

Lecoq R. 1965. Manuel d'analyses alimentaires et d'expertise usuelles. Doin- Deren and Company.

Leveau JY., Bourgeois CM. 1980. Techniques d'analyse et de contrôle dans les industries agro alimentaires. Tech et Doc, Lavoisier.

Peterson DG., Reineccius GA. 2003. Determination of the aroma impact compounds in heated sweet cream butter. Flavour. Fragr. J. 18, 320-324.

Rady AH., Badr HM. 2003. Keeping the quality of cows' butter by $\gamma$-irradiation. Grasas y Aceites 54, 410-418.

Roberts D, Hooper W, Greenwood M.1995. Practical food microbiology. Public Health Laboratory Service, London.

Sagdic O, Arici M, Simsek O. 2002. Selection of starters for traditional Turkish yayik butter made from yoghurt. Food. Microbiol. 19, 303-312.

Vernam AH, Sutherland JP. 1994. Milk and milk products: technology, chemistry and microbiology. Chapman \&Hall, London. 